\title{
THE ROLE OF SELF-APPRAISAL IN HEALH FORMATION AMONG PEOPLE OF DIFFERENT AGE

\author{
Dobrianska O.V., Voloshchuk O.V.
}

\section{РОЛЬ САМООЦПНКИ У ФОРМУВАННП ЗДОРОВ'Я} ОСІБ РІЗНОГО ВІКУ

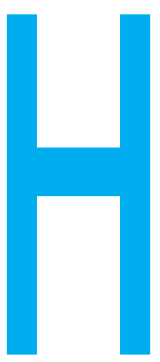

ДОБРЯНСЬКА О.В. ВОЛОЩУК О.В.

ДУ «Інститут громадського здоров'я ім. О.М. Марзєєва НАМН України», м. Київ

Ключові слова: самооцінка, здоров'я населення, віко-статеві групи, соціальне середовище. езважаючи на певну монодисциплінарність системи навчання, зокрема у медичних навчальних закладах, нині все частіше у багатьох дисциплінах людину розглядають з позицій біо-психосоціальної цілісності, яка взаємодіє 3 навколишнім середовищем і характеризується наявністю різнорідних та різнорівневих якостей і явищ - від матеріальних до соціальних і духовних проявів $[1,2]$. При цьому людина належить до певного соціального середовища і $€$ його компонентом.

Питання об'єднання соматичного, психічного і соціального здоров'я людини постають у провідних документах експертів В003, все частіше висвітлюються у пуб- лікаціях дослідників [3, 4]. Здоров'я людини як інтегративна характеристика об'єднує дві цілісності (середовищну і суб'єкта розвитку) та їхню взаємодію на рівні індивіду. Існує так званий «принцип сумісності», згідно з яким ціле відіграє домінуючу роль щодо його частин. Цілісність характеризується наявністю умовно «нижнього» (матеріально зумовленго) і «верхнього» (психосоціального) шарів явищ. Суб'єктивні чинники належать саме до верхнього шару та часто $€$ визначальними у ґенезі різних захворювань. Сучасна медицина, на жаль, розглядає «здоров'я» та «нездоров'я» з позицій симптоматики, тобто напрямку, в якому вивчаються сукупності
РОЛЬ САМООЦІНКИ У ФОРМУВАННІ ЗДОРОВ'Я ОСІБ РІЗНОГО ВІКУ Добрянська О.В., Волощук О.В. ДУ «Інститут громадського здоров'я ім. О.М. Марзєєва НАМН України», M. Київ

Мета роботи. Визначити роль самооцінки у формуванні здоров'я людей різного віку. Об'єкти та методи дослідження. У роботі використано соціологічні, психологічні та математичні методи дослідження. Було розроблено анкету з вивчення самооцінки здоров'я. Проанкетовано респондентів різних вікових груп. Для оцінки суб'єктивної компоненти здоров'я застосували інтегральні показники (індекс самооцінки здоров'я).

Результати. Самооцінка здоров'я відрізняється у людей різних віко-статевих груп: найвищу оцінку здоров'я було відзначено у людей молодого віку (до
25 років). У групі зрілого віку самооцінка здоров'я жінок була вищою порівняно 3 чоловіками. У чоловіків віком понад 61 рік спостерігалося підвищення самооцінки здоров'я, на відміну від жінок, в яких відзначалося ії̈ зниження. Інтегральний індекс самооцінки здоров'я характеризувався низькими критеріями самооцінки здоров'я у жінок 2544 років та високими критеріями у людей літнього віку незалежно від статі.

Висновки. Під час оцінки здоров'я людей різного віку важливо враховувати суб'єктивну її компоненту. Низька самооцінка здоров'я $\epsilon$ фактором ризику для формування нездорових форм поведінки як у молоді, так і в осіб зрілого та літнього віку, що означає необхідність визначення психологічного стану респондентів 3 відхиленнями у самооцінці здоров'я.

Ключові слова: самооцінка, здоров'я населення, віко-статеві групи, соціальне середовище.

\section{() Добрянська О.В., Волощук О.В.

СTATTЯ, 2020. 
Успішне вбудування людини у соціальне середовище $є$ важливим для формування адекватної суб'єктності. Якщо $€$ успішність у соціумі, будуть і передумова, і мотивація для досягнення здоров'я і навпаки. Як приклад, після виходу на пенсію люди частіше хворіють, і пов'язане це не лише з віковими змінами організму, а й з психологічними настановами, наприклад, «у вашому віці в усіх гіпертонія... », «це типові вікові зміни» тощо. Соціальна смерть може призвести і до фізичної.

Специфіка людини полягає у тому, що природа її - біологічна, проте сутність - соціальна. Усі свої потреби людина реалізує через функціонування фізіологічних систем, і ніщо соціальне не реалізується без біологічної субстанції. Іншими словами, біологічна субстанція - реалізатор соціального [6].

Отже, враховуючи вищезазначене, соціальне середовище доцільно вважати важливою детермінантою здоров'я. У зв'язку з цим виникає питання оптимізації соціального середовища, оскільки за умови відсутності комфортного соціального середовища, яке орієнтоване на розвиток людини, фактично немає конструктивних умов для формування повноцінного здоров'я.

На сьогодні стан здоров'я людей у нашій країні можна оцінити як дефіцитарний, що зумовлено дією негативних соціально-економічних факторів, специфікою суспільної свідомості та, що особливо важливо, низьким рівнем відповідальності за стан свого здоров'я [7].

Загальну самооцінку здоров'я населення України за останні 25 років можна охарактеризувати як середню. Усі ці роки переважна більшість українців оцінювала стан свого здоров'я як задовільний (найгірший показник був 1996 року - 48\%, найви- щий - 2004 р. - 58\%), середній бал коливався у діапазоні 2,9-3,1 [7].

у цьому питанні простежуються відмінності між особами різної статі. Чоловіки частіше визнають стан свого здоров'я «відмінним», а про «дуже поганий» і «поганий» стан здоров'я частіше заявляють жінки, хоча тривалість життя у жінок вища за чоловіків. До того ж у жінок гіршими є і показники захворюваності. Жінки частіше за чоловіків мають схильність до хронічних захворювань (різниця становить 10-15\%), частіше хворіють на простудні захворювання, мають довший за чоловіків термін перебування на лікарняному (або постільному режимі) [7].

Серед людей віком понад 55 років частка тих, хто оцінює стан свого здоров'я як дуже поганий і поганий, зазвичай становить 40\%, тоді як серед людей активного працездатного віку таких майже втричі менше, а серед молодих людей віком 18-29 років - менше у чотири рази [7].

Питання стану здоров'я, суб'єктивного його відчуття, а також поведінки, яка сприяє здоров'ю або є ризиковою, стають все більш затребуваними у молодіжному середовищі. Оцінка підлітками і молоддю власного здоров'я, задоволеності життям важлива для розробки профілактичних програм та напрямів промоції здоров'я.

Суб'єктивну оцінку можна розглядати і як інтегральний показник задоволеності підлітків власним здоров'ям, який віддзеркалює наявність скарг або хвороб та психологічне благополуччя дитини.

На самооцінку стану здоров'я підлітків та людей молодого віку мають вплив різні фактори, які пов'язані саме 3 соціальним оточенням та різними формами поведінки. 


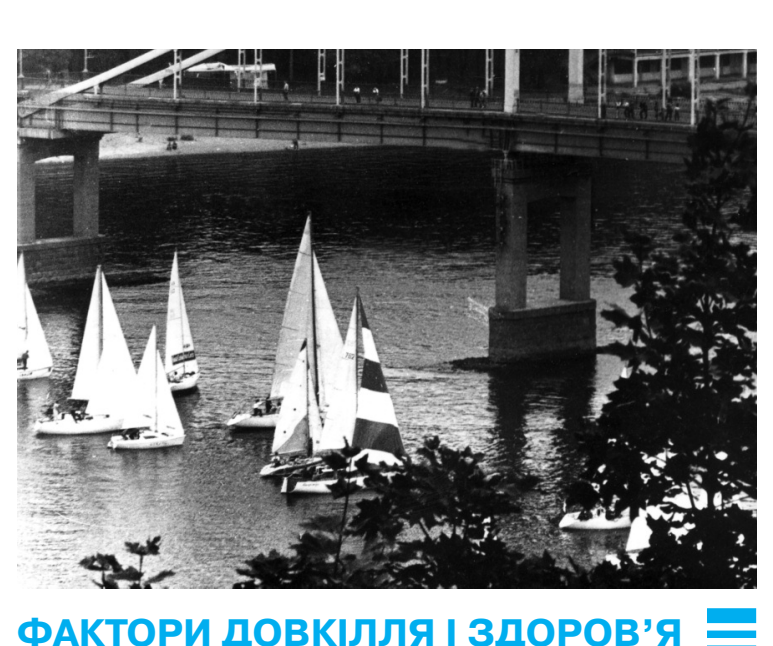

Вивчення питань самооцінки здоров'я підлітками і молоддю проводили дослідники у багатьох регіонах світу. Зокрема, корейські науковці встановили зв'язок самооцінки здоров'я з різними типами здорової поведінки $[8,9]$. Про зв'язок між рівнем самооцінки і рівнем здоров'я говорять канадські науковці [10]. Встановлено зв'язок низької самооцінки здоров'я в європейських підлітків з певними проявами психологічних відхилень (депресії, відчуття безнадії, суїцидальні тенденції, аддиктивні прояви) [11]. Проте у корейських підлітків такий зв'язок не спостерігається, хоча встановлено зв'язок низької самооцінки зі схильністю до гемблінгу [8].

Норвезькі науковці не виявили прямого зв'язку між самооцінкою і рівнем здоров'я $[12,13]$, проте дослідили наявність можливого зв'язку між поганим здоров'ям і відчуттям незадоволеності власним тілом, 3 низьким рівнем соціальної активності (шкільне середовище).

Серед школярів з низькою самооцінкою здоров'я виявляється більш лояльне ставлення до шкідливих звичок, до реклами слабоалкогольних напоїв. Встановлено, що такі діти є більш рекламоорієнтованими, мають більш позитивне ставлення до неї $[14,15]$. Студенти з високою самооцінкою здоров'я, навпаки, більш успішні у шкільних досягненнях, самоконтролі і краще справляються зі стресовими ситуаціями. До того ж такі підлітки частіше відчувають себе щасливими [16].

Враховуючи актуальність даного питання метою нашої роботи було визначити роль самооцінки у формуванні здоров'я осіб різного віку.

Об'єкти та методи дослідження. Об'єктом дослідження була самооцінка здоров'я людей різного віку. Для отримання вихідної інформації було розроблено анкету, яка містила запитання щодо вивчення фізичної, психологічної і соціальної компонент здоров'я і чинників, що на них впливають; питання гендерної ідентичності особистості. Окремо були виділені питання стосовно самооцінки здоров'я респондентами. Були опитані люди різного віку, зокрема студентська молодь м. Києва та м. Луцька (віком до 22 років), люди молодого віку (22-44 роки), люди зрілого віку (45-60 років), літні люди (понад 60 років). Розподіл респондентів за віком проведено на підставі вікової класифікації ВООЗ. Опитування було анонімним, добровільним і конфіденційним.

Для оцінки суб'єктивної компоненти здоров'я на популяційному рівні важливим і необхідним $€$ застосу- вання інтегральних показників. Одним з таких показників $€$ індекс самооцінки здоров'я, запропонований науковцями ФГБУН Інституту соціально-економічного розвитку РАН [17]. В основу розрахунку даного індексу на популяційному рівні покладено суб'єктивну бальну оцінку респондентами стану свого здоров'я: 1 - погане, 2 - посереднє, 3 - добре, 4 дуже добре, 5 - відмінне.

IC $3=\left(1 x q_{i}+2 x q_{2}+3 x q_{3}+\right.$

$$
\left.4 x q_{4}+5 x q_{5}\right): 5 \text {, }
$$

де IC3 - індекс самооцінки здоров'я; $q_{i}$ - частка респондентів, які обрали відповідь $i$.

Даний індекс оцінювали за шкалою коливань від 0,2 до 1 (до 0,6 - низька самооцінка здоров'я, 0,61-0,8 - середня, 0,81-1 - висока самооцінка здоров'я).

Результати. Щодо суб'єктивної оцінки власного здоров'я студентською молоддю (віком до 25 років) вста-

Рисунок 1

\section{Розподіл студентської молоді за самооцінкою здоров'я, \%}

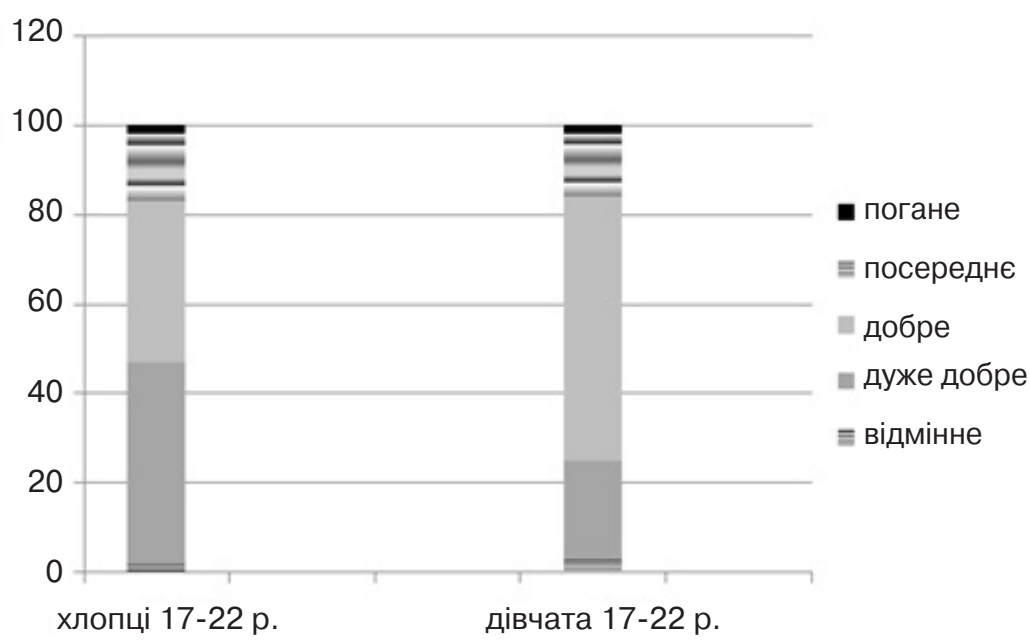

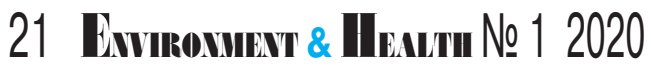


новлено таке: переважна більшість респондентів незалежно від статі оцінила власне здоров'я як «добре» i «дуже добре». Критерій оцінки «дуже добре» здоров'я відзначали майже половина хлопців і кожна п'ята дівчина. Близько 2\% хлопців і 3\% дівчат зазначили, що мають «відмінне» здоров'я. Критерії оцінки здоров'я «посереднє» і «погане» у хлопців і у дівчат практично не відрізнялися. Так, «посереднє» здоров'я відзначено у 15\% хлопців і $14 \%$ дівчат; «погане» - у 2\% хлопців і у $2 \%$ дівчат (рис. 1).

Аналіз суб'єктивної оцінки здоров'я 3 використанням індексу самооцінки здоров'я дозволив встановити низькі показники і у хлопців, і у дівчат (рис. 2).

Критерії оцінки власного здоров'я особами молодого віку (25-44 роки - згідно з класифікацією ВООЗ) розподілилися таким чином: майже половина респонден- тів, незалежно від статі, оцінила власне здоров'я як «добре»; кожен 4-й - як «дуже добре»; «посереднє» здоров'я відзначали кожна п'ята жінка і кожен десятий чоловік; майже однаковою була частка респондентів, які оцінили власне здоров'я як «погане»; рівень суб'єктивної оцінки «відмінне здоров'я» відзначався у кожного десятого чоловіка, а у жінок був відсутнім (рис. 3).

У віковій групі 44-60 років $(47 \pm 6,6) \%$ чоловіків і $(66 \pm$ $5,2) \%$ жінок оцінили власне здоров'я як «добре» $(p<0,05)$. Особливістю самооцінки здоров'я респондентів цієї вікової групи були вищі рівні суб'єктивної оцінки здоров'я у жінок порівняно з чоловіками: близько 2\% жінок суб'єктивно оцінили власне здоров'я як «відмінне»; частка жінок, які оцінили здоров'я як «посереднє», була вдвічі меншою порівняно з чолові-

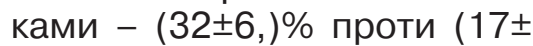
$3,2) \%, p<0,05$.

У групі літніх осіб (віком понад 61 рік) також були встановлені гендерні особливості розподілу самооцінки здоров'я респондентами. Так, половина опитаних чоловіків оцінили власне здоров'я як «добре», що було втричі більше порівняно 3 жінками - $(53 \pm 6,0) \%$ проти $(18 \pm 4,6) \%, \quad p<0,01$. У жінок, навпаки, на 17\% була більшою частка тих, хто оцінив власне здоров'я як «посереднє». Майже кожна п'ята жінка даного віку вважає власне здоров'я «поганим», тоді як жоден чоловік не дав такої оцінки. Високі оцінки здоров'я («відмінне» і «дуже добре») були відсутніми і у чоловіків, і у жінок.

Таким чином, у різних вікових групах спостерігаються певні особливості сприйняття власного здоров'я: частка осіб з найвищими рівнями оцінки здоров'я була вищою в осіб молодого віку незалежно від статі. У групі людей зрілого віку самооцінка здоров'я жінок, порівняно з чоловіками, була вищою. У чоловіків віком понад 61 рік, навпаки, відзначається підвищення самооцінки здоров'я (за рахунок рівня «добре» здоров'я), тоді як у жінок спостерігається зворотний процес.

На підставі розрахованого індексу самооцінки здоров'я було встановлено, що самооцінка здоров'я чоловіками вікової групи 25-44 років відповідає середньому рівню, а жінками цієї вікової групи низькому (рис. 4). у осіб віком 44-60 років величини даного індексу відповідають середнім значенням і у чоловіків, і у жінок. У групі віком понад 61 рік спостерігається тенденція до зростання ін-

\section{Розподіл респондентів за індексом самооцінки здоров'я, \%}

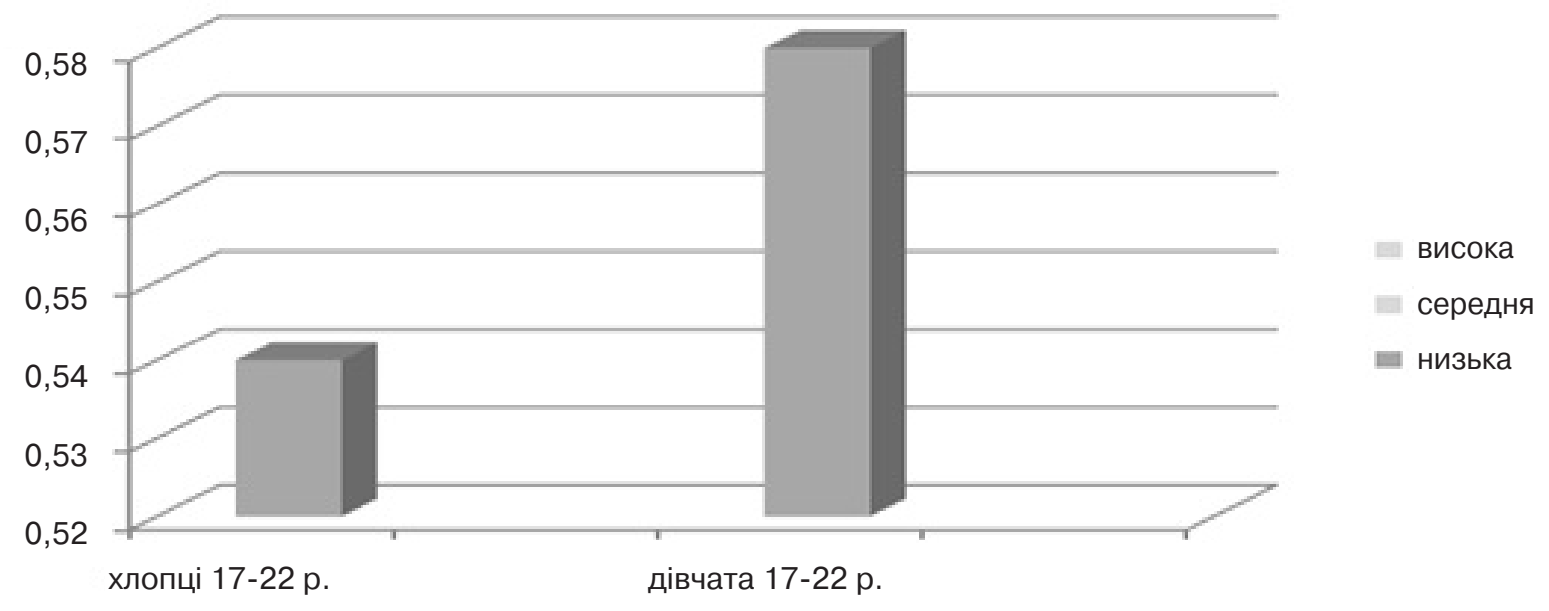


THE ROLE OF SELF-APPRAISAL IN HEALH FORMATION AMONG PEOPLE OF DIFFERENT AGE

Dobrianska O.V., Voloshchuk O.V. SI «O.M. Marzieiev Institute for Public Health, NAMS Ukraine», Kyiv

Objective: We determined a role of self-appraisal in health formation of people of different age.

Materials and methods: We applied sociological, psychological and mathematical methods in the work. We developed the health self-appraisal questionnaire.

The respondents of different age were surveyed. The integral indicators (health self-appraisal index) for the assessment of subjective component of health were used.

Results: Health self-appraisal of people of different age is different: the highest health rate was noted in young people (under 25 years old). In a mature age group, the self- appraisal of health among women was higher in comparison with men. We determined the increase of self-appraisal of health in men older than 61 years old in contrast to women of this age who had its decrease. In women aged 25-44 years old, the integral index of health self-appraisal was characterized with low criteria. And it was evaluated with high criteria in elderly people irrespective of gender.

Conclusions: At the health assessment of people of different age, it is very important to take into account its subjective component. Low self-appraisal of health is a risk factor for the formation of unhealthy forms of behavior among both young and elderly and old people, which means a need to determine the psychological state of the respondents with disabilities in self-appraisal.

\section{Keywords: subjective assessment, population health, gender and age groups, social surroundings.}

дексу - на 0,1 у.о. у чоловіків і на 0,2 у.о. у жінок. Це - у діапазоні середніх значень, проте у жінок наближається до високих показників.

Тобто застосування даного індексу дозволило виявити певні відмінності у самооцінці здоров'я респондентів, зокрема: низьку самооцінку здоров'я жінок 25-44 років; зростання самооцінки здоров'я і у чоловіків, і у жінок віком понад 61 рік, що дещо відрізняється від даних, отриманих фахівцями [7]. Це можна пояснити існуючими розбіжностями у самооцінці здоров'я літніми особами, які працюють та які не працюють [18], і потребує подальшого вивчення за допомогою психологічних методів.

\section{Висновки}

Отже, базуючись на холістичній (біо-психо-соціальній) концепції, важливою $€$ характеристика суб'єктивної компоненти під час оцінки здоров'я населення. Зважа- ючи на те, що самооцінка здоров'я водночас $€$ факторіальною (при формуванні способу життя) і результуючою (при формуванні психосоматичних хвороб) ознаками, необхідно враховувати психо-соціальні особливості особистості у різному віці.

Наявність низької самооцінки здоров'я у підлітків і молоді, людей зрілого віку, наявність дещо завищеної самооцінки здоров'я у літніхлюдей потребують психоло-

\section{Розподіл респондентів різних віко-статевих груп залежно від самооцінки здоров'я, \%}

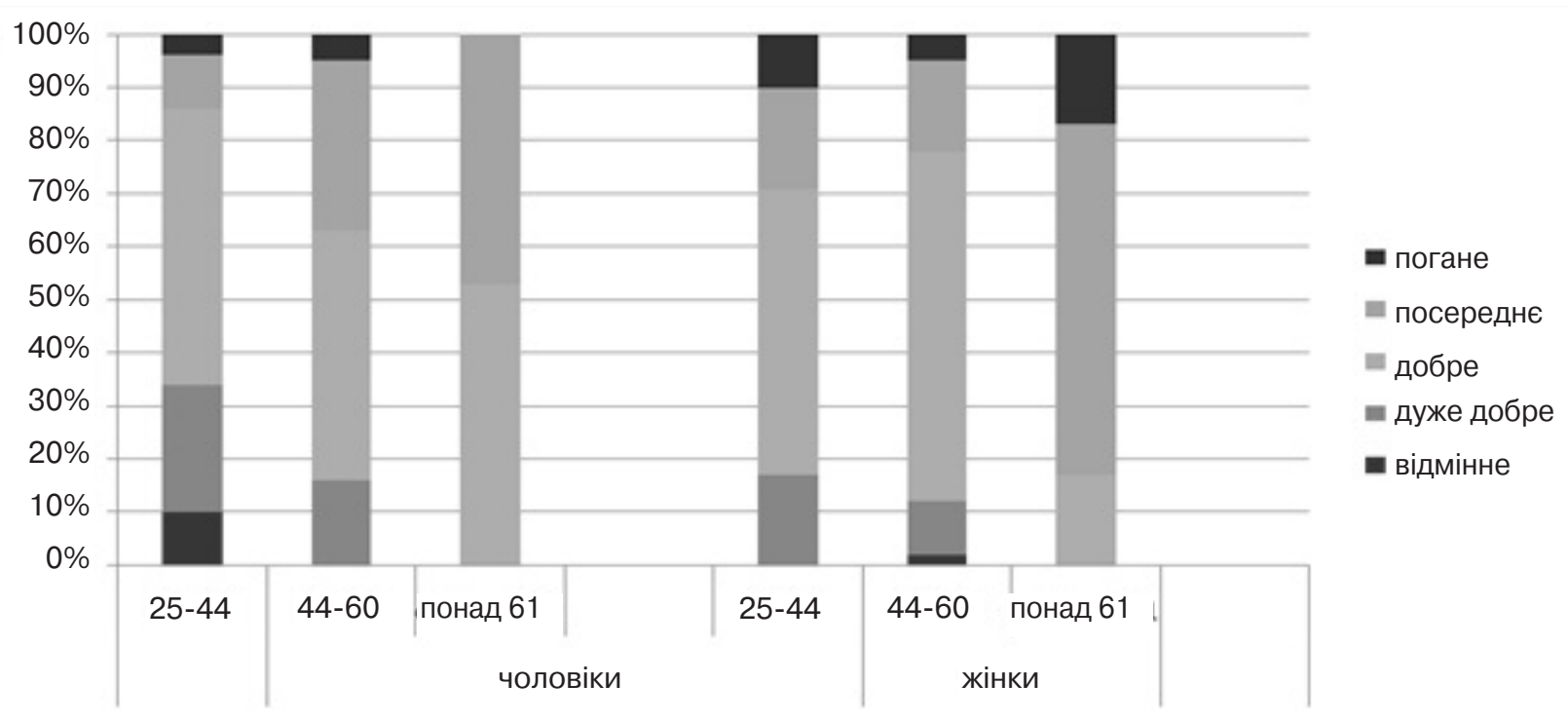

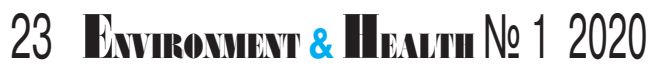


века. Копенгаген : ВОЗ, 2013. 213 c.

5. Сытин Г.Н. Самоубеждение как эффективный метод оздоровления-омоложения. Изд-во Лабиринт Пресс, 2001. 256.

6. Колпина Л.В., Сербай И.Н. К вопросу об определении понятия «социальное здоровье». Среднерусский вестник общественных наук. 2011. № 1. С. 49-56.

7. Соболєва Н., Чепурко Г. Самооцінка стану здоров'я населенням України. Соціальні виміри суспільства : зб. наук. праць. К., 2017. Вип. 9 (20). С. 382-399.

8. Park J., Kim Y.-Ho, Park S.-J., Suh S., Lee H.-J. The relationship between selfesteem and overall health behaviors in Korean adolescents. Health Psychology and Behavioral Medicine. 2016. Vol. 4 (1). P. 175-185

9. Kim J. Correlation of mental health problems with psychological constructs in adolescence: Final results from a 2-years study. International Journal of Nursing Studies. 2003. Vol. 40 (2). P. 115-124.

10. Shields M., Shooshtari S. Determinants of self-perceived health. Health Reports. 2001. Vol. 13 (1). P. 35-52.

11. Mann M., Hosman C.M.H., Schaalma H.P., de Vries N.K.
Self-esteem in a broad-spectrum approach for mental health promotion. Health Education Research. 2004. Vol. 19 (4). P. 357-372.

12. Moksnes U.K., Eilersten M.E., Lazarewich M. The association between stress, self-esteem and depressive symptoms in adolescents. Scandinavian Journal of Psychology. 2016. Vol. 57. P. 22-29.

13. Meland E., Haugland S., Breidablik H.-J. Body image and perceived health in adolescence. Health Education Research. 2007. Vol. 22 (3). P. 342-350.

14. Пересипкіна Т.В.

Суб'єктивна оцінка здоров'я дітей, соціальні детермінанти його формування. Современная педиатрия. 2018. № 4 (92). C. 44-48.

15. Breidablik H.-J., Meland E., Lydersen S. Self-rated health in adolescence: a multifactorial composite.

Scandinavian Journal of Public Health. 2008. Vol. 36 (1).

P. 12-20.

16. Бончук Н.В. Суб'єктивне розуміння щастя сучасною молоддю та підлітками. Молодий вчений. 2016. № 5 (32). С. 542-548.

17. Шабунова А.А., Корчагина П.С. Влияние самосохранительных компо- основы европейской политики и стратегия для XXI

Розподіл респондентів різних віко-статевих груп за індексом самооцінки Рисунок 4 здоров'я, \%

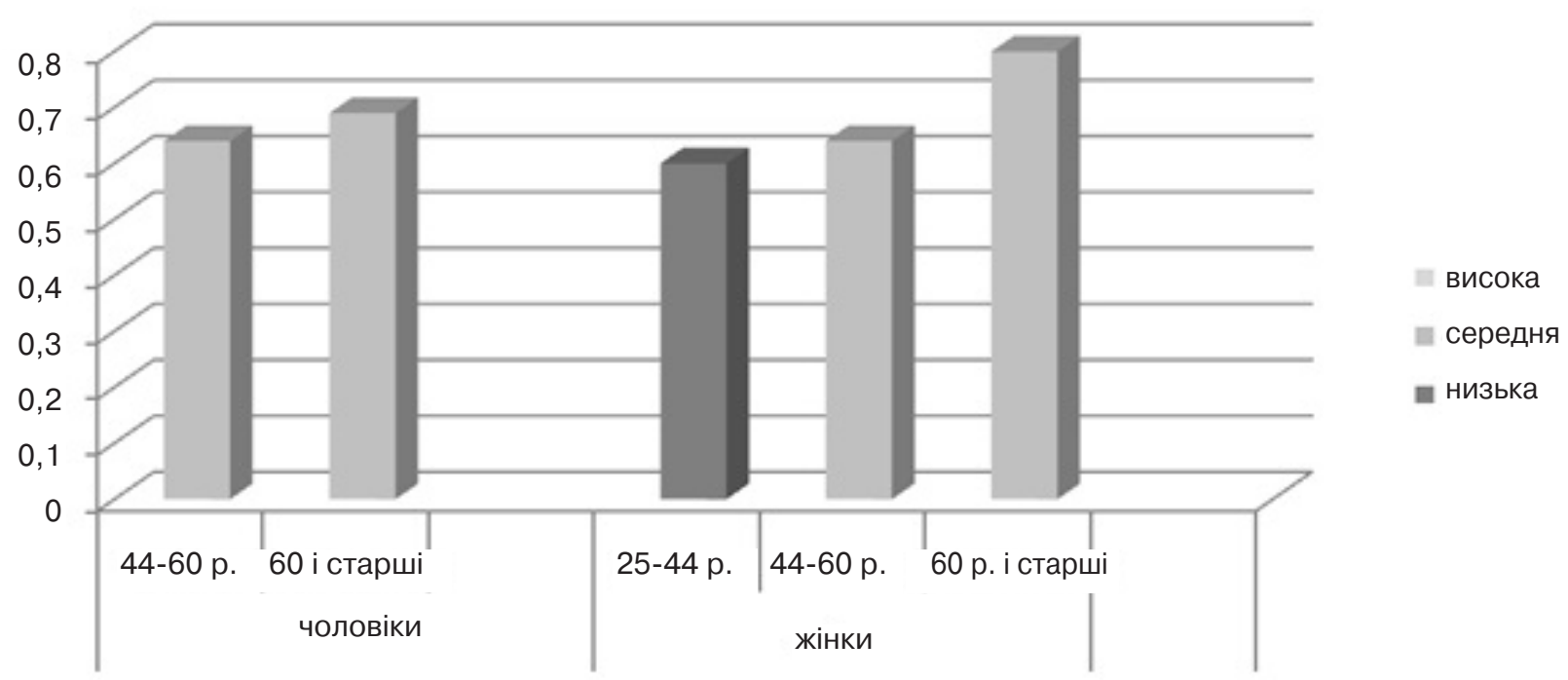


РОЛЬ САМООЦЕНКИ В ФОРМИРОВАНИИ ЗДОРОВЬЯ ЛЮДЕЙ РАЗНОГО ВОЗРАСТА Добрянская О.В., Волощук Е.В. ГУ «Институт общественного здоровья им. А.Н. Марзеева НАМН Украины», г. Киев

Цель работы. Определить роль самооценки в формировании здоровья людей разного возраста.

Объекты и методы исследования. $B$ работе использованы социологические, психологические и математические методы исследования. Была разработана анкета по изучению самооценки здоровья. Были проанкетированы респонденты разных возрастных групп. Для оценки субъективной компоненты здоровья использовали интегральные показатели (индекс самооценки здоровья).

Результаты. Самооценка здоровья отличается у людей разных возрастнополовых групп: наивысшая оценка здоровья была отмечена у людей молодого возраста (до 25 лет). В группе зрелого возраста самооценка здоровья женщин была выше по сравнению с мужчинами. $у$ мужчин старше 61 года наблюдалось повышение самооценки здоровья, в отличие от женщин, у которых отмечалось ее понижение. Интегральный индекс самооценки здоровья характеризовался низкими критериями самооценки здоровья у женщин 25-44 лет и высокими критериями у людей пожилого возраста независимо от пола.

Выводы. При оценке здоровья людей разного возраста важно учитывать субъективную его компоненту. Низкая самооценка здоровья является фактором риска для формирования нездоровых форм поведения как у молодежи, так и у лиц зрелого и пожилого возраста, что означает необходимость определения психологического состояния респондентов с отклонениями в самооценке здоровья.

\section{Ключевые слова: самооценка, здоровье населения, возрастно- половые группы, социальная среда.}

нентов на наличие хронических заболеваний и самооценку здоровья населения. Здравоохранение РФ. 2014. № 1. С. 40-43.

18. Фирсова Н.Г. Научные ведомости Белгородского государственного университета. Сер.: Гуманитарные науки. 2012. Вып. 16. № 24 (143). C. 218-225.

REFERENCES

1. Kelasiev V.N., Pervova I.L. and Poluektova N.M. Vestnik SPbSU. 2016 ; Ser. 12 (1) : 15-26. doi :

$10.21638 / 11701 /$ spbu 12.201

6.102 (in Russian).

2. Kelasiev V.N. and Pervova I.L. Vestnik SPbSU. 2014. Ser. 3. Issue 1 : 163-170 (in Russian).

3. Self-Assessment Tool for the Evaluation of Essential Public Health Operations in the WHO European Region. Copenhagen : WHO ; 2015 : $105 \mathrm{p}$.

4. Health 2020: A European Policy Framework and Strategy for the 21-st Century. Copenhagen : WHO ; 2013 : 213 p.

5. Sytin G.N. Samoubezhdenie kak effektivnyi metod ozdorovleniyaomolozheniya [SelfPersuasion as an Effective Method for Recovery and Rejuvenation]. Labirint Press ; 2001 : 256 p. (in Russian).

6. Kolpina L.V. and Serbay I.N. Srednerusskiy vestnik obshchestvennykh nauk. 2011

; 1 : 49-56 (in Russian).

7. Soboleva N. and Chepurko H. Samootsinka stanu zdorovia naselenniam Ukrainy [Self-Appraisal of the Health by the Population of Ukraine]. In : Sotsialni vymiry suspilstva : zb. nauk. prats. [Social Dimensions of Society: Coll. of Scientific Works]. Kyiv ; 2017 ; 9 (20) : 382-399 (in Ukrainian).

8. Park J., Kim Y.-Ho, Park S.-J., Suh S., Lee H.-J. Health Psychology and Behavioral Medicine. 2016 ; 4 (1) : 175-185.

9. Kim J. International Journal of Nursing Studies. 2003; 40 (2) : 115-124.

10. Shields $M$. and Shooshtari S. Health Reports. $2001 ; 13$ (1) : 35-52.

11. Mann M., Hosman C.M.H., Schaalma H.P. and de Vries N.K. Health

Education Research. 2004 ; 19 (4) : 357-372.

12. Moksnes U.K., Eilersten M.E. and Lazarewich M. Scandinavian Journal of Psychology. 2016 ; 57 : 22-29.

13. Meland E., Haugland S. and Breidablik H.-J. Health Education Research. 2007 ; 22 (3) : 342-350.

14. Peresypkina T.V. Sovremennaya pediatriya. 2018 ; 4 (92) : 44-48 (in Ukrainian).

15. Breidablik H.-J., Meland E. and Lydersen S. Scandinavian Journal of Public Health. 2008 ; 36 (1) : 12-20.

16. Bonchuk N.V. Molodyi vchenyi. 2016 ; 5 (32) : 542548 (in Ukrainian).

17. Shabunova A.A. and Korchagina P.S. Zdravookhranenie Rossiyskoy Federatsii. 2014 ; 1 : 40-43 (in Russian).

18. Firsova N.G. Nauchnye vedomosti Belgorodskogo gosudarstvennogo universiteta. Ser.: Gumanitarnye nauki. 2012 ; 24 (143), Iss. 16 : 218225 (in Russian).

Надійшло до редакції 18.12.2019 